\title{
Christian Religion Education as a Solution for Families to Face the Change in the Era of Revolution 4.0
}

\author{
Djoys Anneke Rantung ${ }^{1}$, Lamhot Naibaho ${ }^{2 *}$ \\ ${ }^{1}$ Magister of Christian Religion Education, Universitas Kristen Indonesia, Jakarta \\ ${ }^{2}$ English Education Department, Universitas Kristen Indonesia, Jakarta. \\ Corresponding Author: lamhot.naibaho@uki.ac.id
}

\begin{abstract}
This article is about the appropriate Christian Religious Education models for families in dealing with changes in the Era of Industrial Revolution 4.0. The rapid development of science and technology has caused significant changes to society so that the family as the smallest unit in society is always affected. The Industrial Revolution 4.0 provides an opportunity for families to access various information easily, both positive and negative information and to be able to connect to all people in this world without any limits. The Industrial Revolution 4.0 points to changes in a global economic activity centred on digital technology integrated with physical and biological. This research was conducted at the Universitas Kristen Indonesia, with the research method used was library research. To answer the problem in this research, the researcher examines theories related to the problem under study, sourced from books, national and international articles in proceedings and journals, documents and other sources. This study's findings are that the relevant model of Christian religious education is applied to face challenges for families in facing changes in the Industrial Age 4.0. Namely, the holistic-transformative Christian Religious Education model can integrate all church resources connected with all the resources in society in preparing church members and Christian families to participate in change.
\end{abstract}

\section{Keywords: Industrial revolution 4.0, Christian Education Religion, Family, Holistic-transformative}

\section{INTRODUCTION}

Revolution is often interpreted as a significant change, fast and radical. According to the Big Indonesian Dictionary, "revolution" is: "a fairly fundamental change in a field". The term "industrial revolution" is given the meaning: "a radical change in the effort to achieve production by using machines, both for movers and processors" (KBBI, no date). Until now, the world's civilisation has experienced at least four industrial revolutions. 1700 was an industrial revolution in the mechanical field. The use of steam to drive engines in factories in many ways is beneficial to humans. Mass production no longer requires much human labour. Its change is called the Industrial Revolution 1.0. (Akmal, 2019) Then followed a very radical change when electricity replaced steam. Assembly and mass production are assisted by electricity, which is more effective and massive. Once again, it has an impact on humans and society. It is called R Industrial 2.0 evolution. This revolution took place at the end of the 19th century.

After that, human civilisation entered the industrial revolution 2.0, a big change also occurred. Changes in this era are called IR 3.0. Industrial evolution, namely the development of science in the fields of chemistry, nuclear and so on. In the 21st century, another significant change occurred. The term that was later popular to refer to this change was "Industrial Revolution 4.0" (from now on abbreviated IR 4.0). This revolution is based on the "Industrial Revolution 3.0", namely digital technology for manufacturing. The impact of the change is very massive, affecting various fields, namely economic, social, political, cultural and religious. "The 'Fourth Industrial Revolution' even challenges the concept of what it means to be human." (World Economic Forum and Asian Development Bank, 2017)

Humans are the subject of society. An individual is a part of the family. Family and society are the essential community of the country. According to William J. Goode, as quoted by Rustina, the family is the smallest unit in society that consists of two types, namely nuclear family consisting of father, mother, and child. The second type is the extended family. (Rustina, 2014) According to Law No. 52 of 2009 concerning Population Development and Family Development, the family is: "... the smallest unit in a society consisting of husband and wife, or husband, 
wife, and children, or father and child, or mother and child.

The family is part of the community. The family is part of the changes that occur in society, the country, and the world. According to Paulus Tangdilintin, studies of changes in the family began to attract sociologists' attention since the mid-19th century. The main thing that drives these studies is the development of social life in Europe and America, which is strongly influenced by the modern industry's growth. These early studies focused on family settings and changes in society. (Paulus Tangdilintin, 1999) In the mid-19th and early 20th centuries, studies of families changed pressure. No longer on family institutions, but more attention to social problems concerning changes in the family. "

In the study of Christian Religious Education (PAK)1. The family in perceiving the faith community. The family and the Church have an essential role in the teaching of faith for every Christian individual. Horace Bushnell, an American theologian in PAK who wrote the book Christian Nurture states, family (household) and congregation are the context for PAK. (Robert R. Boehlke, 2009; Naibaho, 2019a, 2019b). According to EG Homrighausen and IH Enklaar, PAK is the basis for other education. According to them, the meaning of family for Christianity guess $\mathrm{n}$ dung in a metaphorical statement about God in an atmosphere and family circumstances. (EG Homrighausen, 2008)

Meanwhile, according to George Albert Coe, PAK's whole process is, "... fostering Christian experience in and through social interactions of educators." Therefore, for him, the Christian family must take part in the renewal and reconstruction of a social ethos that reciprocity affects individuals and families' lives. (Thomas H. Groome, 2010) In anthropology-sociology studies and PAK studies, families are understood as subjects in a constantly changing society. Specifically, the PAK study program, on the one hand, the focus is on the family as a faith community such as the church/church. On the other hand, it is understood that the family is a fellowship that is the target of change and must also participate in changes that occur in the community.

Based on the descriptions remarks theory, linked with the contemporary social situation, which has been, is being and will take place, then the problems that the writer enjoyable to study is: "How Christian religion education become a solution for families to face the change in the Era of Revolution 4.0?

${ }^{1}$ PAK stands for Pendidikan Agama Kristen, who is mean by Christian religious education
Therefore, this article will focus on discussing these problems. Thus, the purpose of writing this article is to describe thoughts and reflect theologically around the problem of paradigms and models of PAK for families in the context of RI's change 4.0. Thus in this article, the author will describe the understanding, phenomena, and impacts of RI 4.0, then thoughts around the family during change, and the main discussion, namely the paradigm and model of PAK for families facing these changes.

The research method for this article is library research. Relevant literature and discussion topics become sources of data to describe and analyse.

\section{LITERATURE REVIEW}

The term "Industrial Revolution 4.0" comes from the name of the German government's national strategic initiative program Ministry of Education and Research or the Ministry of Education and Research or the Ministry of Economic and Energy Affairs: "Industry 4.0". This program aims to drive digital manufacturing progress by increasing digitisation and interconnection of products, value chains, and business models. This program also aims to support research, industrial partner networks, and standardisation. This program was launched in 2011. (European Commission, 2019)

Martin, in his article on the site cleverism.com, explained the meaning of RI 4.0 as follows: "This Cyber-Physical system consists of smart machines, storage systems, and production facilities that can exchange information independently, trigger actions and control each other independently. It facilitates fundamental improvements to the industrial processes involved in manufacturing, engineering, use of materials and supply chains and life cycle management. " (Martin, 2017)

The evolution of Industry 4 refers to the automation process in manufacturing with the use of technology for flexible mass production (Big Indonesian Dictionary (KBBI), no date). The use of digital technology allows machines to work independently or cooperate with humans. The machine becomes an independent entity capable of gathering data, analysing it, and giving advice. (Martin, 2017) The evolution of Industry 4 is not only about manufacturing production activities. This revolutionary change influences broader life, encompassing many social changes related to work, industry-specific and technology. (Industry 4.0: the fourth industrial revolution - a guide to Industrie 4.0, no date) 
As the Industrial Revolution 1.0, 2.0 and 3.0 previously, Revolution Industri 4.0 also significantly affect human beings as individuals, families, and society in many ways. With mass production in manufacturing, society's consumption patterns will become easy, as if they are not limited, and as such, they have an influence on work, relations between individuals and ways of interpreting life.

"Every revolution is a complicated process with extensive outside influence in society."(Akmal, 2019). Experts, academics and practitioners are generally optimistic about the evolution of Industry 4 for humans and their communities. The evolution of Industry 4 is considered to offer and opportunities to improve the welfare of society in general. Such as increasing the average income per capita in the world, improving the quality of life of people, and extending humans' life span. (Raymond R Tjandrawinata, no date)

As the smallest unit in society, the family consists of individuals who are directly integrated with society and the state. The existence of each individual or family is inseparable from the country's political and economic policies. Directly, individuals and families become part of the changes at the local, regional, national and global levels. The digital age of Industrial Revolution 3.0, or even before globalisation and even industrialisation far backwards, has integrated every individual and family into a global citizen. Every civilisation has what is called a "family". Therefore this institution has its history in world civilisation. Historians and anthropologists who examine the family in various aspects, such as other historical research topics, divide family history periodisation at several stages. Prehistoric times, historical times, modern times, and contemporary eras, and that periodisation also wants to explain the family's existence in each period of change.

Peter Burke cites a classic book in sociology entitled L'organization de la Familie (1871) by Frederic Le Play, distinguishing three types of families. The first type, 'patriarchal', is a boy who has been married but still lives at home with his parents. The second type, "unstable", namely the "nuclear" or "conjugal" family, that is, all married children move out of the house. The third type, between the two types, is the type of "root family" ( familie sonche), where only one married son still lives with parents. (Peter Burke, 2015) Three types of families, according to Le Play, refer to the chronological order of change in families in European nations. "... in the early Middle Ages (in the sense of a large family group)), then became a root family at the beginning of the modern era, until finally changing to the nuclear family which is characteristic of industrial society". (Peter Burke, 2015) This development resulted in what he called the automation effect. (Paulus Tangdilintin, 1999)

However, another somewhat different theory was put forward by Peter Laslett and his friends from the Study Group on Population and Social Structure in Cambridge and other countries, such as the Netherlands. Laslett and his group classify families into three types. The first type is simple (short family), then the second type, extended (extended family) and the third multiple (compound family). (Peter Burke, 2015) William F. Ogburn (1886-1959), as discussed by Tangdilintin, brought up the theory of adaptive culture in families. "The collapse of traditional culture, according to Ogburn resulted in the emergence of a new type of family life, which emphasises personality functions." (Paulus Tangdilintin, 1999) This theory wants to show that changes in the family system result from developments or changes in technology. Changes that occur in material culture (technology, one of which) result in changes in adaptive culture, namely the habits, beliefs, and philosophies practised and embraced by the community.

However, Burke, in several types, the family remains as an "institution consisting of a set of interdependent and complementary roles ..." In addition to economic and legal units, the family for Burke is also a moral community, namely as a group of identities and a place for the emotional involvement of each member. (Peter Burke, 2015) What is at the core of the family is kinship which is always the basis in dealing with and going through any changes in society. Thus, the conclusion that can be drawn is that the family is an institution or partnership that always tries to be stable in facing societal changes.

\section{METHOD}

This research was conducted at the Universitas Kristen Indonesia, with the research method used was library research. It was done from July to September 2019. The research is the key instrument of this research. The researcher collected the data of this research which is needed to answer the problem in this research by examining the theories related to the problem under study, sourced from books, national and international articles in the form of proceedings and journals, documents and other sources, and then the data is gathered and analysed descriptively. 


\section{DISCUSSION}

In the Indonesian context, for Muhidin M. Dahlan in the introduction to the book, Happy Families: Nine Memories of Indonesian Family Wounds," ... every family has a meaning, every house plot has a narrative." For Dahlan, modern Indonesia's family history (since the order a long time until the new order) is inseparable from the country's political discourse. That is seen in the existing family metaphors ranging from school classes to the palace: "Father Teacher," Mother Teacher "in the classrooms to" Father Country "and First Lady" in the palace, especially in the New Order era. When the family becomes a state affair, for example, with the term "Pancasilais Family" or through the "10 PKK Programs", it becomes family politics. (Muhidin M. Dahlan, 2017)

On the one hand, politics greatly influence Indonesian families' existence, but on the other hand, changes in society by technological developments are also very influential. Family members, as individuals, always have to do socialisation in order to exist. According to R. Dinarti F. So'oed, the socialisation process occurs through social interaction. Socialisation is also the process of transmitting intergenerational culture. Without socialisation, the community cannot continue the regeneration process. Quoting David A. Goslin, So'oed said, "Socialisation is a learning process experienced by a person to obtain knowledge, skills, values, and norms so that he can participate as members in his community group." (R. Dinarti F. So'oed, 1999)

The development of information technology in the digital era and especially in the era of IR 4.0 impacts family life. Revolutionary gadgets or communication gadgets make children, for example, become individuals who are independent of the care of their parents. (Wahyu Saefudin, 2019) Yet according to Revelation Saefudin, "effective communication in the family will lead to openness, trust, quality of relationships, and the inner atmosphere cosy." (Wahyu Saefudin, 2019) Families everywhere are in a changing society. Entering the era of IR 4.0, families cannot avoid the effects of change. The Church has always played a role as a companion for Christian families through the changes that occur. One form of assistance it is the teaching of PAK. In each of these changes, the Church is encouraged to continue to think about the paradigm and model of PAK that can accompany Christian families to live their lives in light of God's Kingdom's vision.

The concept of family in the Bible is to create God (Gen. 1: 27-29; 2: 21-25). In the creation story in
Genesis 1 and 2, people who live in pairs (Adam and Eve) in place right in the garden, in the world where human life. This human or family live with other creatures. God equips this human with knowledge and the will to build a life. The biblical section of Genesis contains humans who have families in an intimate relationship with God. However, sin has damaged that relationship (Gen. 3). Humans then have to strive for their lives in the awareness of the sin that always shadows it.

The family is the basis of the Church. The Church carries out community service, deaconia, and preaching, targeting first the family, community, and world. Ferry C. Lewier wrote that education in the family is essential for every child to succeed outside the family. "Because if the family is sick, the church and the nation will get sick. And if the family dies, the church and the nation will also die." (Ferry C. Lewier, 1998). The Church has essential responsibilities for the family, and the family has a large role for the Church. Church and family are faith communities that are integrated.

A community is a community formed by shared fundamental value and proceed in the form of kinship relations. Authentic faith, according to Groome, "comes from the activity of God with a complete human being and his identity." "Christian faith is an expression of a Christian." (Groome, no date a) For Groome, to be and remain a Christian requires a Christian faith community. PAK has an essential role in the formation and maintenance of faith communities. Groome did not first directly mention that the family is of the Christian faith. Nevertheless, for the writer, the Christian family must also be understood as a community of faith, namely, relationships, interactions, and educational platforms for individual socialisation. The family as a community of faith is the smallest kinship group in the community who lives the Christian faith as each individual's identity.

Maurice Eminyan, SJ goes even more profound by defining the family as a community of love, living community, and the safety community. These family definitions all carry the ideal meaning of family, which Eminyan calls "every family should be a family according to God's plan and redemption." (Maurice Eminyan, 2001) The family is a space and a place for individuals to go through the process of learning about God's works.

Following sociologists' way of thinking, Groome accepts that interactions between individuals and society or the socio-cultural world occur dialectically. According to Groome, the dialectical relationship means that the socio-cultural context does not entirely 
change the identity of individuals, and thus individuals can change their social reality. (Groome, no date b) PAK is a project to promote knowledge and praxis about the kingdom of God. Thus, for the writer, the PAK model that can be projected to answer the challenges of changing IR 4.0 for Christian families is PAK oriented towards moral transformation and open and creative behaviour. The PAK model paradigm is the family as a community of faith that is always changing towards the vision of God's Kingdom. Therefore, as a faith community, the family and Church will always direct their existence to the Kingdom of God. Such is the foundation (paradigm) of every Christian family to have a dialogue with the reality of the socio-cultural context, which will enter a significant change in the era of RI 4.0. RI 4.0 comes with a change fairly radical in many aspects that will undoubtedly impact human existence: individuals, families, and communities in social, cultural and religious. Integration of digital technology weapons with hardware devices and humans in a system of mutually connected making activities became massive and mass production. It then gives a very significant impact on the level and manner of public consumption of products that have been constructed in the digital era, such as gadgets to the forms and processes of public services ( health, education, to bureaucracy ) which in the RI era 4.0 is predicted to be increasingly fast, easy and affordable.

RI 4.0 is an era where humans are supported by computer intelligence continually being updated in moving hardware devices. Human involvement will be less in terms of work to produce products that serve their needs. Thus, humans should have more time and opportunity to think about higher quality things about living together, about nature that needs to be preserved and about their relationship with God.

Digital devices, both soft and hard, can never replace humans in the role of maintaining an increasingly quality life spiritually and intellectually. Such is the case with faith or belief in God, all of which are supporters of RI 4.0 will never make people irreligious. It is precisely when health services, education, and other public affairs get better because of digital technology. People and society will increasingly try to find the most profound meanings of life: their relationship with God, nature, and their relationships with fellow humans.

According to Groome, the essence of PAK is "... as a political activity with pilgrims who deliberately they pay attention to the activities of God in the present. Paying attention to the Christian faith community's story, which is realised in the present, and the Vision of the Kingdom of God to come, the seeds of the
Kingdom of God that have been present between us. Christian religious education has the task of deliberately guarding and sustaining our three essential time dimensions in productive tension - past, present and future.

Facing changes in the era of IR 4.0, the Church that runs PAK activities for families requires a full PAK model, which integrates all resources and elements: Church, theological school, community, and technological intelligence. All of these are integrated resources to transform lives based on and aim at the Kingdom of God's vision.

\section{CONCLUSION}

In the Republic of Indonesia in 4.0 Era, as the authors have pointed out in the discussion above, in addition to several possible impacts on family life, the opportunities and opportunities available in this era need to be responded to intelligently by the Church in reconstructing contextual paradigms and models of PAK. Christian families through PAK are guided and directed to respond to the changes that will occur in the era of RI 4.0 based on the nature and paradigm of PAK, namely the task of developing knowledge about the vision of the Kingdom of God.

Era RI 4.0 integrates digital technology, hardware that supports public activities and services with humans. The experts call the work system that covers all dimensions and fields in terms of physical systems and cyber-social systems. These two terms designate a process that integrates digital technology with both physical and social activities in society. In this article, the author has shown that PAK model for families that needs to be reconstructed in the face of changes in the RI era 4.0 is holistic-transformative. A model that integrates all the Church resources is in connection with all available resources in the community in preparing citizens of churches and Christian families to participate in the change. This PAK model aims to develop knowledge about the Kingdom of God's vision that is practically manifested in ethical actions or actions in carrying out social innovations to overcome problems in society.

\section{REFERENCES}

[1] Akmal (2019) Closer to Industry 4.0. Yogyakarta: Deepublish.

[2] Ayu (no date) Social Innovation.

[3] Big Indonesian Dictionary (KBBI) (no date) the meaning of 'manufacturing'. Available at: 
https://kbbi.web.id/manufaktur (Accessed: 12 September 2019).

[4] EG Homrighausen, I. E. (2008) 'Christian Religious Education', in. Jakarta: Bpk Gunung Mulia, pp. 130-131.

[5] European Commission (2019) 'Digital Transforation Monitor, Germany: Industrie 4.0 January 2017'.

[6] Ferry C. Lewier (1998) 'PAK Management', in Andar Ismail (ed.) Teach Them to Perform: a collection of Essays on Christian Religious Education. Jakarta: Bpk Gunung Mulia, p. 209.

[7] Industry 4.0: the fourth industrial revolution - guide to Industrie 4.0 (no date) i-Scoop. Available at: https://www.i-scoop.eu/industry-4-0/.

[8] KBBI (no date) revolution. Available at: https://www.kbbi.web.id/revolusi (Accessed: 11 September 2019).

[9] Martin (2017) Industry 4.0: Definition, Design Principles, Challenges, and the Future of Employment, Cleverism. Available at: https://www.cleverism.com/industry-4-0/,.

[10] Maurice Eminyan, S. (2001) Family Theology. Yogyakarta: Canisius.

[11] Muhidin M. Dahlan (2017) Memories of Family Wounds (in) Indonesia: An Introduction. Fairuzul M. Yogyakarta: Radio Buku.

[12] Naibaho, L. (2019a) 'Teachers' Roles on English Language Teaching: A Students Centered Learning Approach', International Journal of ResearchGranthaalayah, 7(4), pp. 206-212.

[13] Naibaho, L. (2019b) 'The Integration of Group Discussion Method Using Audio-Visual Learning Media toward Students' Learning Achievement on Listening'.

[14] Naibaho, L. (2014). The Role of Education and Culture in the Development of Character and Civilization of the Plural Indonesian Nation. Jurnal the Ary Suta Center Series on Strategic Management, 27(0), 69

[15] Nitia Agustina Kala Ayu (no date) Opportunity for Social Innovation in the Industrial Revolution 4.0: How did it develop in Indonesia? Yogyakarta.

[16] Paulus Tangdilintin (1999) 'A Glimpse of the Development of Urban Family Studies', in Family Sociology Vocabulary. ed. TO Ihr. Jakarta: Obor Indonesia Foundation, p. 1.

[17] Peter Burke (2015) 'History and Social Theory', in. Jakarta: Indonesian Torch Library Foundation, pp. 77-78.

[18] R. Dinarti F. So'oed (1999) The Socialization Process. ed. TO Ihr, Family Sosilogi Rampai. ed. TO Ihr. Jakarta: Obor Indonesia Foundation.

[19] Raymond R Tjandrawinata (no date) Industry 4.0: the industrial revolution of the century and its influence on the field health and biotechnology, Working Paper from Dexa Medica Group. Available at:

https://www.researchgate.net/publication/293695551 (Accessed: 2 February 2016).

[20] Robert R. Boehlke (2009) History of Mind d early practice of Christian education: From John Amos Comenius to $B$ Indonesia Economic PAK in Indonesia. Jakarta: Bpk Gunung Mulia.

[21] Rustina (2014) 'Families in Sociologist Studies', MUSAWA, 6(2), pp. 287-322. Available at: https://media.neliti.com/media/publications/114514ID-kelamily-dalam-kajian-sosiologi.pdf.

[22] Thomas H. Groome (2010) 'Christian Religious Education: Sharing Our Stories and Vision', in. Jakarta: Gunung Mulia, p. 173.

[23] Tyas, E. H., \& Naibaho, L. (2020). A harmony among of religious community is required amidst the covid-19 pandemic. International Journal of Research-GRANTHAALAYAH, 8(9), 422-428.

[24] Wahyu Saefudin (2019) Restoring the Function of the Family. Kubu Raya: Idea Publishing.

[25] World Economic Forum and Asian Development Bank (2017) ASEAN 4.0: What Does the Fourth Industrial Revolution Mean for Regional Economic Integration? Geneva / Philippines. 